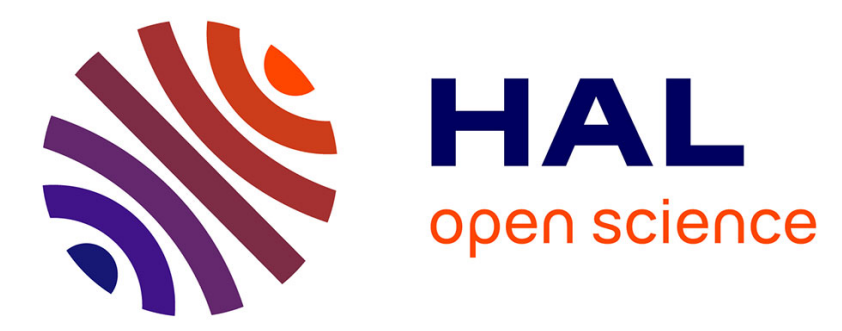

\title{
Evaluation of Sustainable Mass Customized Habitation: The Case of CAP 44
}

\author{
Alexande Chadeneau, Emilie Dol, Solène Martinez, Catherine Da Cunha
}

\section{To cite this version:}

Alexande Chadeneau, Emilie Dol, Solène Martinez, Catherine Da Cunha. Evaluation of Sustainable Mass Customized Habitation: The Case of CAP 44. IFIP International Conference on Advances in Production Management Systems (APMS), Sep 2014, Ajaccio, France. pp.238-245, 10.1007/978-3662-44736-9_29. hal-01387872

\section{HAL Id: hal-01387872 \\ https://inria.hal.science/hal-01387872}

Submitted on 26 Oct 2016

HAL is a multi-disciplinary open access archive for the deposit and dissemination of scientific research documents, whether they are published or not. The documents may come from teaching and research institutions in France or abroad, or from public or private research centers.
L'archive ouverte pluridisciplinaire HAL, est destinée au dépôt et à la diffusion de documents scientifiques de niveau recherche, publiés ou non, émanant des établissements d'enseignement et de recherche français ou étrangers, des laboratoires publics ou privés.

\section{(c)(1)}

Distributed under a Creative Commons Attribution| 4.0 International License 


\title{
Evaluation of sustainable mass customized habitation: the case of CAP 44
}

\author{
Alexande Chadeneau, Emilie Dol, Solène Martinez, Catherine da Cunha \\ LUNAM UNIVERSITE, ECOLE CENTRALE DE NANTES - IRCCYN UMR CNRS 6597 - 1 \\ Rue de la Noë, Nantes, France
}

\begin{abstract}
Measuring the value of a product before launching its production is a way to assure its good sale. The present study proposes a methodology to evaluate the intrinsic value of an habitation. The value is measured in terms of sustainability and customization.

The methodology is composed of a first step of determination of value drivers, an evaluation step, an aggregation step and finally recommendation. step

The methodology is applied on a real case: the CAP 44 housing project in Nantes, France.
\end{abstract}

Keywords. Satisfaction, Customization, Home, Evaluation

\section{Introduction}

Mass customization is a policy than enables the satisfaction of personalized requirements with near mass production efficiency. Among other benefits, it enables to gain competitive advantage on a given market share.

Mass customization can be offered either via product variability or process variability (Daaboul et al., 2011). Numerous researches identify the existence of Mass customization enablers but also of pitfalls (Gilmore and Pine, 1996, da Silveira et al., 2001, Fogliatto et al., 2012).

A raise in customization may lead to a raise in complexity, in the production as well as in management (Blecker et al., 2006). A company should then address several questions before implementing mass customization (Daaboul et al., 2010):

- Can the product be customized?

- Does the customer want a customization?

- Is the company ready for mass customization?

Barlow et al. 2003 reported that Mass customization, which is already functional for Japanese housing industry, could be a new business model for the European one. The challenge is the evaluation of the value of this new type of habitation.

First theories on value go back to ancient Greece (with Plato and Epicurus). Modern research also has interest in this area, promoting transdisciplinary definition and evaluation for this concept (Gallarza et al., 2006) (Ueda et al., 2009). Value is neither a constant in time nor an objective characteristic. Yet this characteristic has a huge 
influence on the customer behavior, particularly on product choice, repeated purchases and product recommendation.

For the particular product which is a "home" the value concept is declined into an elicited valuation named "Housing satisfaction". This indicator measures the proximity of an current and ideal housing of an individual subject to its needs, expectations and achievements (Amérigo \& Aragonés, 1997).

The article is structured as follows: section 2 presents the methodology. Section 3 depicts the use case. Conclusion and research directions close the article

\section{Methodology}

We followed a generic methodology to evaluate the value of a given product (Daaboul et al, 2011).

1. Identification of the Housing satisfaction drivers

2. Determination of a test population for the drivers' weighting

3. Weighting of the satisfaction drivers

We adapted this methodology to the housing product and add to this 3 first steps a final step of aggregation.

\subsection{Housing satisfaction drivers identification}

It is mandatory to define the limits of the product. In our case of housing, we limited the product to the private volume belonging to one or several people. The building as a whole, the neighborhood, transportation systems are then exterior elements that should not be considered.

Thanks to a study led by the French housing sector (Century 21, 2010) an exhaustive list of satisfaction drivers has been established. A reduction of this list to the most pertinent ones was done with the architectural staff of the CAP 44 project, see figure 1 for a hierarchical representation. 


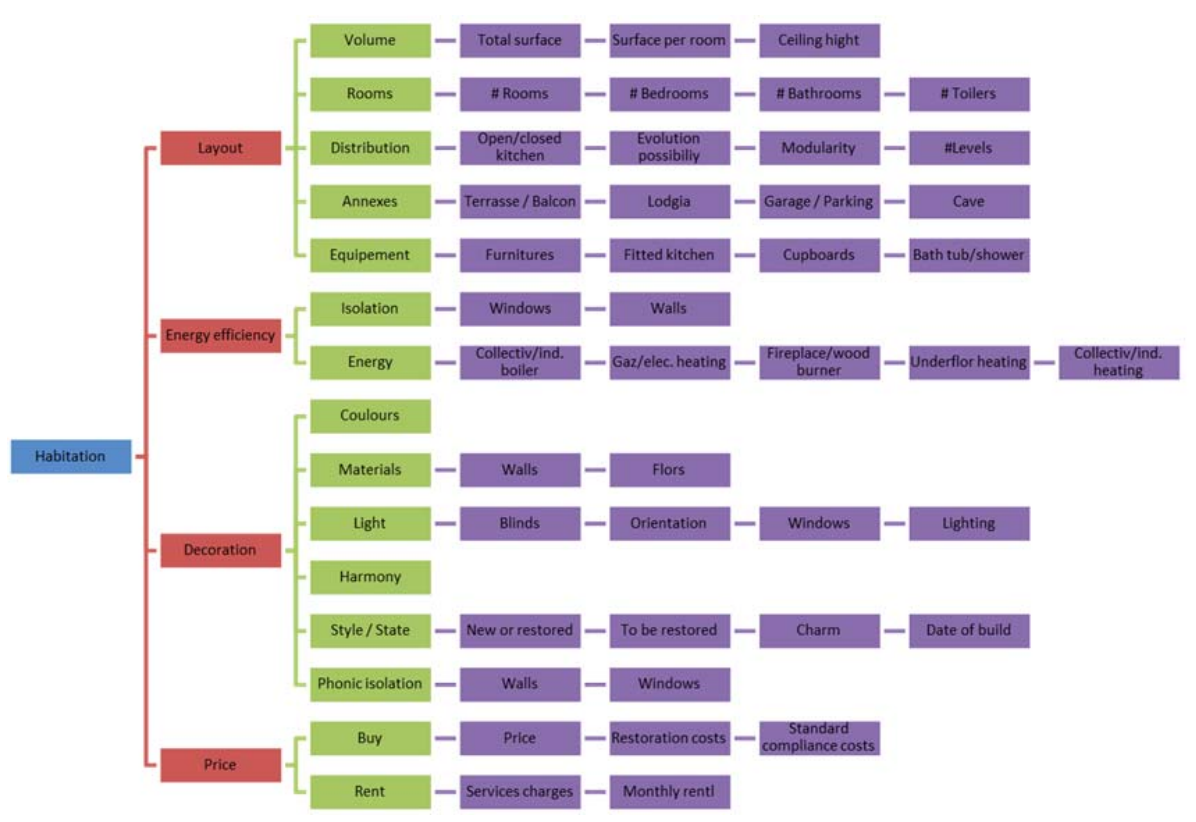

Fig. 1. Satisfaction drivers

\subsection{Evaluations and aggregation.}

For multicriteria evaluation, Analytic Hierarchy Process (AHP) (Saaty, 2008) is often used to weight the different criteria. One of the difficulties in implementing AHP is to limit the number of pairwise comparison the test population has to perform. Therefore a hierarchical partitioning of the criteria can be done, the pairwise comparison will then be limited to criteria belonging to the same subset. The tree representation of those drivers is given in figure 1 .

A difficulty occurs when the decomposition levels are not equal for every driver. We choose to address this issue using sparse pairwise-comparison matrices (Tan and Promentilla, 2013)

The aggregation phase has a significant impact on the obtained results. The choice of aggregation type must answer to two questions:

- What is the most efficient mean type?

- When do we have to use it? On the comparisons? On the weight?

We chose to use the geometric mean which is the most congruent with pairwise comparison (Adamcsek, 2008). The order of the operation also has an impact on weighting. The mean can be done either on the comparisons or on the weights (figure 2) 


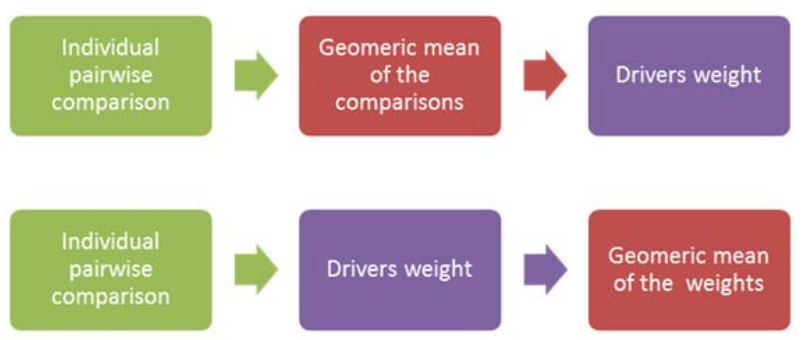

Fig. 2. - Aggregation solutions

The choice between the 2 aggregations

\section{Usecase: the CAP 44 project}

\subsection{Project description}

CAP 44 is a building that followed Nantes's evolution since its building in 1895. At first was a flourmill, ideally placed along the river Loire, and then it has been transformed into offices.

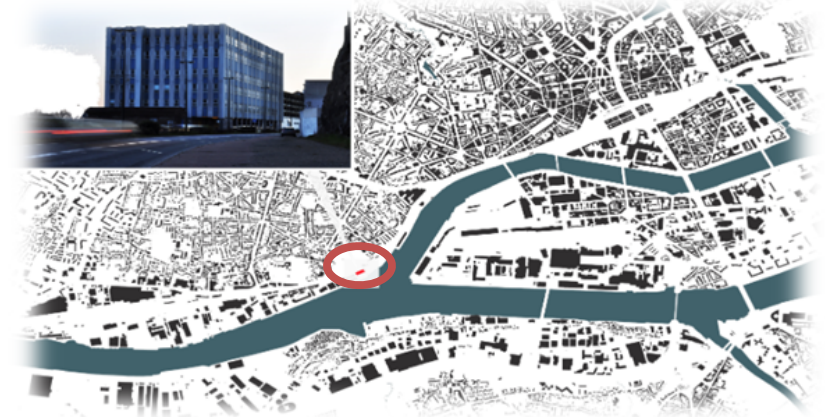

Fig. 3. - Localization of CAP 44 building

Today the city wants to transform this building and use it as the center of a new neighborhood based on the "fertile city" concept. The future building should be a meeting point offering housing, offices place, restaurants, services, etc. figure 4 presents the proposed evolution of the building. 

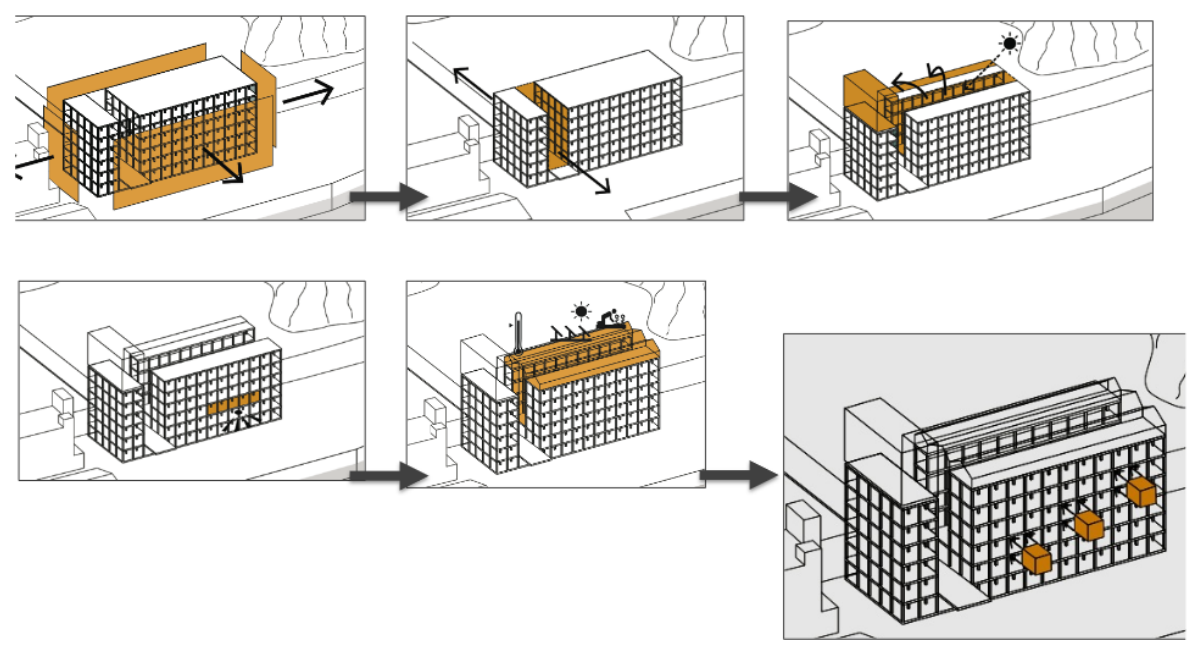

Fig. 4. - Evolution of CAP 44

The chosen redevelopment is modular. The architects wish to pre-build the housing and offices and then insert them into the structure, in a Plug \& Play approach. This idea of a common plateform for different product is in line with mass customization policies (Martin, 1999).

\subsection{Satisfaction drivers and housing evaluation}

To weight the satisfaction drivers, a small panel (30 people) of engineer-architect students, civil engineers, real estate agents, Nantes inhabitants was formed and questioned. The AHP method was applied, it gives the following results. The ten most important drivers are the same, see table 1 . Yet for some drivers the relative difference can be up to $56 \%$ therefore the 2 aggregations will be conserved for the evaluation phases.

\begin{tabular}{lcc}
\hline Drivers & $\begin{array}{c}\text { Geometric mean of the in- } \\
\text { dividual weights }\end{array}$ & $\begin{array}{c}\text { Geometric mean of the } \\
\text { individual comparison }\end{array}$ \\
\hline Rent & $12,86 \%$ & $35,38 \%$ \\
$\#$ of rooms & $5,63 \%$ & $3,76 \%$ \\
$\#$ of bedrooms & $5,42 \%$ & $3,62 \%$ \\
Orientation & $4,51 \%$ & $2,73 \%$ \\
$\#$ of widows & $4,16 \%$ & $2,52 \%$ \\
Service charges & $4,01 \%$ & $11,03 \%$ \\
Evolution possibility & $3,92 \%$ & $2,62 \%$ \\
Levels & $3,58 \%$ & $2,39 \%$ \\
Surface per room & $3,34 \%$ & $2,23 \%$ \\
Fitted kitchen & $2,81 \%$ & $1,88 \%$ \\
\hline
\end{tabular}

Table 1. Weight for the 10 most important Drivers 
For the evaluation, the housing project was described through: artist's interpretations, 2D-plans and synthesis tables related to satisfaction drivers (surface in $\mathrm{m} 2$, description of the heating characteristics,...). Based on this information (which was then unbiased by the interviewer) subjects had to evaluate the housing on a 5-scale basis for each of the 47 drivers. Figure 5 illustrates the variation of the evaluations for 7 of our subjects, the evaluation are given in the y-axis while the drivers are represented in the $\mathrm{x}$-axis.

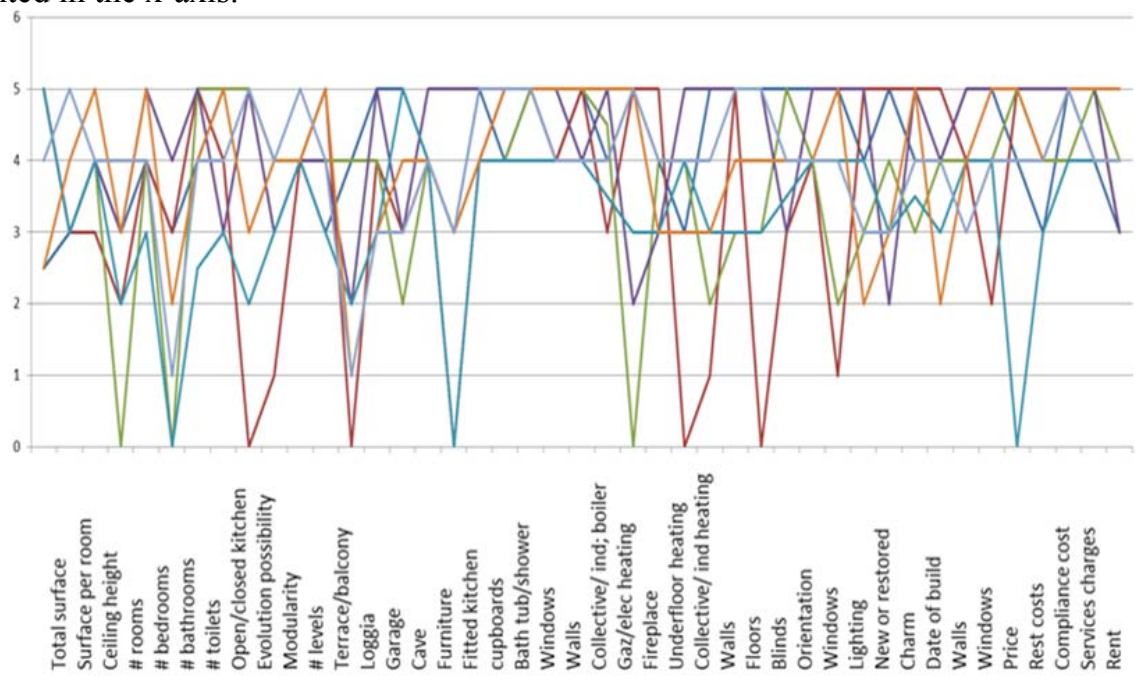

Fig. 5. Evaluation of the drivers

A special category of drivers can be identified: the ones having an evaluation of 0 resp. 5. These drivers are deal-breakers resp. mandatory for other subjects. These drivers are:

- Fireplace/Wood burner

- Garage/Parking

- Furniture

- Walls material

- Numbers of toilets

- Terrace/balcony

Those drivers are of great interest for a mass customization point of view. They should constitute a set of "modules" that the customers could chose or not.

Figure 6 presents the average weighted evaluation for the different drivers per categories. 


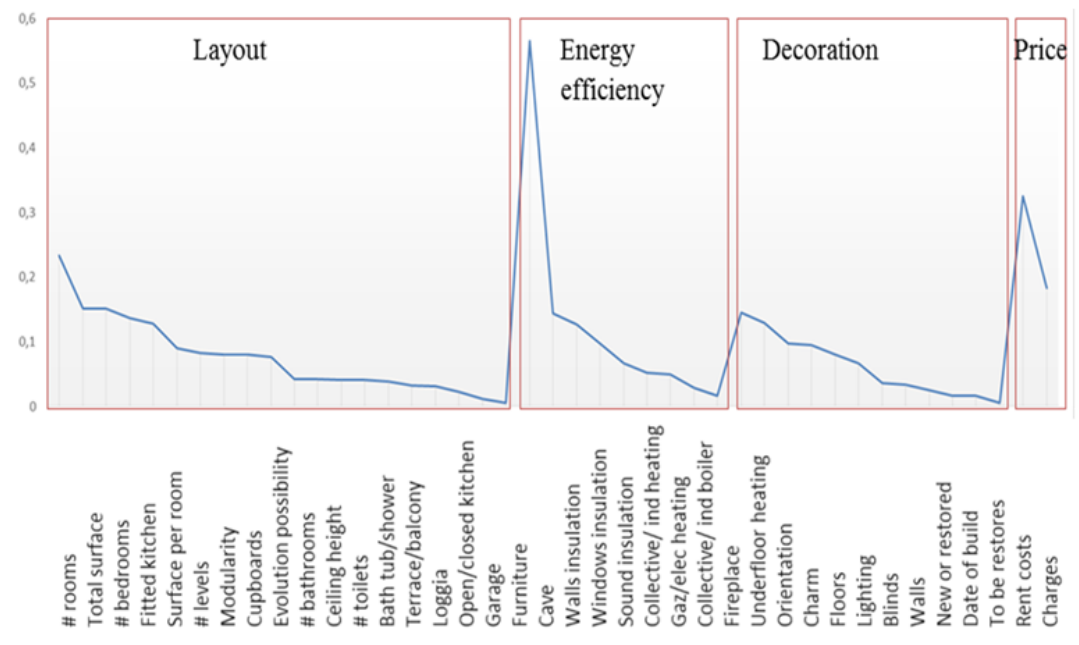

Fig. 6. Average grade of drivers, per category

The drivers having the highest weighted grades are: Total area, Walls isolation, Windows, Services charges.

The average grade of the housing is of 3.92. This evaluation is a reference for further evolution of the project. It should be improved, while the architects take the subjects into account. For instance the initial design proposed a plug-in loggia for each apartment. Thanks to this analysis, they identify that the global preference goes to either a balcony or an extra-room to the housing.

\section{Discussion and conclusion}

This study enriches a methodology of Housing satisfaction evaluation. The application to a housing project validates the relevance of the different steps.

The Cap 44 project's architects used the results of the satisfaction drivers' identification and evaluation to better understand the expectation of future users and then to modify the design of the building. Next steps of the projects include in an evaluation of the new design.

Further research should address the genericity of the obtained drivers and the robustness of their weight for the French housing sector. The stabilized Housing satisfaction evaluation grid could then be used for future building development project in Nantes.

\section{$5 \quad$ References}

1. Adamcsek, E., 2008. The Analytic Hierarchy Process and its Generalizations, Master thesis, Eötvös Lorand University 
2. M. Amérigo, J.I. Aragonés. "A theoretical and methodological approach to the study of residential satisfaction", Journal of Environmental Psychology, 17, pp. 47-57, 1997

3. J. Barlow, P. Childerhouse, D. Gann, S. Hong-Minh, M. Naim, et R. Ozaki, «Choice and delivery in housebuilding: lessons from Japan for UK housebuilders », Building Research \& Information, vol. 31, $\mathrm{n}^{\mathrm{O}} 2$ 2, p. 134-145, 2003.

4. N. Blecker, T.and Abdelkafi, B. Kaluza, et G. Friedrich, «Controlling variety-induced complexity in mass customisation: a key metrics-based approach », International Journal of Mass Customisation, vol. 1, no 2-3, p. 272-298, 2006.

5. Enquête Century21, 2010-2011. Le logement idéal des français. http://photosv5.century21.fr/pdf/201101_c21_logement_ideal.pdf

6. J. Daaboul, C. da Cunha, A. Bernard, and F. Laroche, « Design for Mass Customization: Product variety vs. Process variety », CIRP Annals - Manufacturing Technology, vol. 60, no 1 , p. 169-174, 2011.

7. G. Da Silveira, D. Borenstein, et F. Fogliatto, « Mass customization: literature review and research directions », International Journal of Production Economics, vol. 72, $\mathrm{n}^{\mathrm{o}} 1, \mathrm{p}$. $1-13,2001$.

8. F. S. Fogliatto, G. J. C. da Silveira, et D. Borenstein, « The mass customization decade: An updated review of the literature ", International Journal of Production Economics, vol. $138, n^{\circ} 1$, p. $14-25,2012$.

9. M. G. Gallarza and I. Gil Saura, «Value dimensions, perceived value, satisfaction and loyalty: an investigation of university students' travel behaviour », Tourism Management, vol. 27, no 3, p. 437-452, juin 2006.

10. J. Gilmore et J. Pine, « The four faces of mass customization », Harvard Business Review, vol. 75, p. 91-101, 1997.

11. M. Martin, «Design for variety : a methodology for developing product plateform architectures », Standford university, 1999.

12. Saaty, T. L., 2008. Decision making with the analytic hierarchy process, International Journal Services Sciences, 1(1), 83-98.

13. R. R. Tan et M. A. B. Promentilla, «A methodology for augmenting sparse pairwise comparison matrices in AHP: applications to energy systems ", Clean Techn Environ Policy, vol. 15, no 4, p. 713-719, août 2013.

14. K. Ueda, T. Takenaka, J. Váncza, and L. Monostori, « Value creation and decision-making in sustainable society », CIRP Annals - Manufacturing Technology, vol. 58, no 2, p. 681-700, 2009 